\title{
Diprion pini L. (Hymenoptera, Symphyta, Diprionidae) population dynamics in the Low Dnieper region
}

\author{
Valentyna Meshkova ${ }^{1} \bowtie$, Serhii Nazarenko ${ }^{2}$, Maryna Kolienkina ${ }^{3}$ \\ ${ }^{1}$ Ukrainian Research Institute of Forestry and Forest Melioration named after G. M. Vysotsky, Pushkinska 86, \\ Kharkiv, 61024, Ukraine, phone: +38-097-371-94-58, e-mail: valentynameshkova@gmail.com \\ ${ }^{2}$ Kherson State Agrarian University, Stritenska 23, Kherson, 73009, Ukraine \\ ${ }^{3}$ Kharkiv National University of Urban Economy named after O. M. Beketov, Marshal Bazhanov 17, Kharkiv, 61002, \\ Ukraine
}

\section{Abstract}

Pine sawflies (Hymenoptera, Symphyta, Diprionidae) are the most spread foliage browsing insects of pine forests in Europe, especially monovoltinous European pine sawfly Neodiprion sertifer (Geoffroy, 1785) and common pine sawfly Diprion pini (Linnaeus, 1758), which develops in one or two generations per year depending on weather. The outbreaks of both pine sawflies are the most frequent and intensive in the Steppe zone of Ukraine, especially in the Low Dnieper region, where pine forest (Pinus sylvestris Linnaeus and Pinus pallasiana D. Don) was planted on moving sands in the sixties of the $20^{\text {th }}$ century. This research is aimed at the evaluation of the parameters for D. pini outbreak dynamics in the Low Dnieper region.

Outbreak severity, specific foci area and mean score of stand threat by $D$. pini were evaluated from the regional statistical reports. In the regional scale for 1979-2017, notable outbreaks of D. pini were registered in 1982, 1993, 2002, 2006 and 2017. An interval between maximums was from 4 to 11 years, in average 9 years. The growth of foci area in 1979-1998 as compared to 1999-2017 as well as correlation between pine stand area and annual area of this pest's foci in different forests was not statistically significant. Graphical analysis of dynamics of D. pini focal area for 2010-2017 was done based on individual threat levels. Our study confirms the fact of three outbreaks for this period in three forest and hunting enterprises (FHE), two outbreaks in one FHE and one outbreak in one FHE. An interval between the outbreaks makes three or six years. The causes of such shortening of interval are discussed.

\section{KEY WORDS}

Diprion pini, Low Dnieper sands, outbreak severity, outbreak frequency

\section{INTRODUCTION}

Climate change in the last decades has become unfavourable for forest health in many regions and favourable for forest pests (Neuvonen and Viiri 2017). The severity, fre- quency and duration of many foliage browsing insects increases in the new conditions (Meshkova and Davydenko 2011; Haynes et al. 2014, 2018; Ziesche 2017).

Pine sawflies (Hymenoptera, Symphyta, Diprionidae) are the most spread foliage browsing insects, 
which damage Pinus sylvestris Linnaeus, Pinus pallasiana D. Don and some other pine species in the forests of Europe (Geri 1988; Barre et al. 2002; Blomqvist et al. 2016), particularly in Ukraine (Meshkova and Davydenko 2011; Meshkova and Kolienkina 2016).

European pine sawfly Neodiprion sertifer (Geoffroy, 1785) is a monovoltine insect and damages pine needles of the previous year (Schwenke 1964; Nevalainen et al. 2015). Common pine sawfly Diprion pini (Linnaeus, 1758) consumes all the needle year classes (Kosunen et al. 2017) and develops in one or two generations per year (Geri 1988; Möller et al. 2017). Several types of this insect generation development are known in Ukraine. It sometimes has only spring generation (swarming in May and larvae feeding in May-June), and in other cases, only autumn generation (swarming in August and larvae feeding in August-September) (Meshkova 2009). A certain percentage of cocoons of each generation stay in diapause, which lasts sometimes for several years, and its cessation is often impossible to predict. Unexpected swarming of sawflies from diapausing cocoons, rapid population growth and forest damage in the end of summer is characteristic for this species (Schwenke 1964; Sharov and Safonkin 1982; Eichhorn 1983; Geri 1988).

In Ukraine, the annual area of $D$. pini outbreaks exceeds 30 thousand hectares, and that of $N$. sertifer exceeds 25 thousand hectares (Meshkova and Davydenko 2011). The outbreaks of both pine sawflies are the most frequent and intensive in pine plantations of the Steppe zone (Meshkova 2009), especially in the Low Dnieper region, which includes the high part of Kherson region and Ochakivske Forest Enterprise of Nikolaiv region (Vinogradov 1964).

Our research of monovoltinous N. sertifer population dynamics in Low Dnieper region showed only one outbreak for eight years (2010-2017) with maximum in 2012 in the forest stands of the most analysed forest enterprises. Period with the threat of forest damage over $50 \%$ during outbreak did not exceed three years (Meshkova et al. 2017). Considering the relations between seasonal development of foliage browsing insects and their population dynamics (Meshkova 2009) and above mentioned features of D. pini seasonal development, this research was aimed at evaluation of the parameters for $D$. pini outbreak dynamics in the Low Dnieper region.

\section{MATERIAL AND METHODS}

Low Dnieper region (the so called Oleshkovsky sands before the thirties of the $20^{\text {th }}$ century) is located $30 \mathrm{~km}$ east of the city of Kherson and $30 \mathrm{~km}$ from the Black Sea coast. Over 150 thousand hectares of sands were formed in the glacial era, and many centuries ago, these were covered with forest (Vynogradov 1964). As a result of excessive grazing and felling, the forests were destroyed, and the sands became mobile. Attempts of their afforestation were unsuccessful until the middle of the $20^{\text {th }}$ century, when the weather conditions became rather favourable for the survival of pine seedlings, and effective insecticides (DDT) were found to control root pests (especially Scarabaeidae). Over 80 thousand hectares of pine stands ( $P$. sylvestris and $P$. pallasiana) were planted (Nazarenko 2000).

Statistical reporting materials for 1979-2017 were obtained from the State Specialized Forest Protection Enterprise (SSFPE) 'Khersonlisozahyst', which together with detailed data for 2010-2017 from the State Enterprises (SE) 'Velykokopanivske Forest and Hunting Economy' (FHE) (46²9'12" N 32 58'29" E), 'Holo-

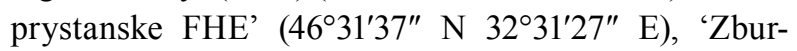
yivske FHE' $\left(46^{\circ} 28^{\prime} 22^{\prime \prime} \mathrm{N} 32^{\circ} 25^{\prime} 01^{\prime \prime} \mathrm{E}\right)$, 'Tsurupinske FHE' (46 37'06" N 3243'08" E) of Kherson Regional Administration of Forest and Hunting Management, and SE 'Ochakivske FHE' (46 $36^{\prime} 46^{\prime \prime}$ N 31 $32^{\prime} 59^{\prime \prime}$ E) of Mykolaiv Regional Administration of Forest and Hunting Management were used in the analysis of the area of $D$. pini foci.

Area of pine stands ( $P$. sylvestris and P. pallasiana) in the forest fund of mentioned forest $\&$ hunting enterprises was calculated using the forest inventory database of Production Association 'Ukrderzhlisproekt' (as of 01.01.2011).

Outbreak severity was evaluated as mean annual area and specific area of $D$. pini foci in the forest fund of the mentioned forest $\&$ hunting enterprises. Specific foci area was calculated as the ratio of absolute foci area (in hectares) to pine stands area in the forest fund of the mentioned enterprises (thousand hectares) (Meshkova 2009).

In view of the differentiated assessment of forest damage within the focus of $D$. pini in each year, we evaluated the mean score of stand threat $(T)$ by this pest (1): 


$$
T=\frac{\left(a_{1} \cdot 1+a_{2} \cdot 2+a_{3} \cdot 3+a_{4} \cdot 4\right)}{\left(a_{1}+a_{2}+a_{3}+a_{4}\right)}
$$

where:

$T \quad-$ the mean score of stand damage threat,

$a_{1}, a_{2}, a_{3}, a_{4}$ - the stand area with certain threat levels: up to $25 \%, 26-50 \%, 51-75 \%$ and over $75 \%$, respectively; according to this, score 1 corresponds to up to the $25 \%$ threat, score $2-26-50 \%$, score 3 $-51-75 \%$, and score 4 - over $75 \%$.

Descriptive statistics was calculated for the annual area of D. pini for 1999-2017 and in 1979-1998. Correlation between pine stand area and mean (2010-2017) area of $D$. pini foci in different FHE as well as between foci area dynamics for 2010-2017 in each FHE was evaluated. Data on the outbreak severity in different periods of time and in different FHE were subjected to analysis of variance (ANOVA). All the mentioned calculations were performed using Statistica ${ }^{\circledR} 7.0$ (StatSoft, Inc., Tulsa, OK, USA).

\section{Results}

As the massive pine forests have been planted in the Low Dnieper region only in the middle of the $20^{\text {th }}$ century, they were inhabited at first by the so called 'pests of young plantations'. The first colonies of pine sawflies, which migrated from rare natural forests, were killed during plantation treatment with insecticides against pine bark bug (Aradus cinnamomeus Panzer, 1806: Heteroptera, Aradidae) and pine shoot moth (Rhyacionia buoliana Denis and Schiffermueller, 1775: Lepidoptera; Tortricidae). After the cessation of pine forests spraying with insecticides and the pine age exceeded 20-30 years old, the foci of foliage browsing insects began to spread in these stands (Nazarenko 2000). In 1981-1983, the outbreak of D. pini was not intensive and long (Fig. 1), but since 1991, the foci of this pest developed almost without a break in different stands of the region and covered 24,800 hectares of the 80,000 hectares (over $30 \%$ of all the pine forests of the region).

For the period 1979-2017, five notable maximums of area of $D$. pini foci were registered in 1982, 1993, 2002, 2006 and 2017 (see Fig. 1). An interval between

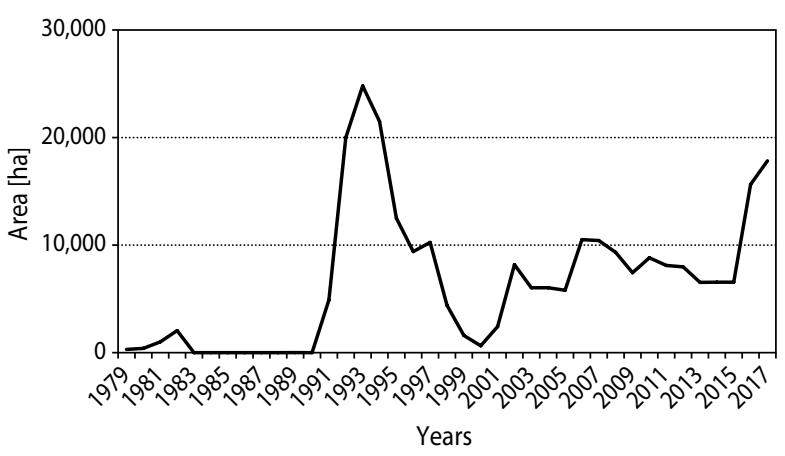

Figure 1. Dynamics of area of Diprion pini foci in the Low Dnieper region in 1979-2017

maximums was from 4 to 11 years, in average 9 years. At the same time, only the first outbreak had clear time limits.

Further outbreaks started in different years in different stands and their duration strongly depended on the timing and quality of the control measures. Therefore, it seemed that the outbreaks were continuous, and annual foci area after 2002 never decreased below 6000 ha up to the sharp increase since 2015 (see Fig. 1).

Although the total and mean annual area of D. pini foci was 1.5 times more in 1999-2017, than in 1979-1998, but the difference was not significant $\left(\mathrm{F}_{\text {fact }}=1.55 ; \mathrm{F}_{0.05}=4.1 ; \mathrm{P}=0.22\right)($ Tab. 1$)$.

Table 1. Statistics of Diprion pini foci area in the forests of the State Forest and Hunting Enterprises of the Low Dnieper region for two periods (1979-1998 and 1999-2017)

\begin{tabular}{|l|c|c|}
\hline \multirow{2}{*}{ Statistics } & \multicolumn{2}{c|}{ Values for periods* } \\
\cline { 2 - 3 } & $1979-1998$ & $1999-2017$ \\
\hline Mean annual foci area, hectares & $5,575.4$ & $8,172.0$ \\
\hline Range, hectares & $0-24,800$ & $640-17,835$ \\
\hline Standard error of the mean & $1,816.65$ & $1,020.43$ \\
\hline Variance & $66,004,597$ & $20,825,406$ \\
\hline $\begin{array}{l}\text { Specific foci area, hectares of } \\
\text { focus } \\
\text { per 1000 hectares of pine stands }\end{array}$ & 114.9 & 168.4 \\
\hline
\end{tabular}

* The difference between 1979-1998 and 1999-2017 is not significant $\left(\mathrm{F}_{\text {fact }}=1.55 ; \mathrm{F}_{0.05}=4.1 ; \mathrm{P}=0.22\right)$.

The forests of the five analysed forest and hunting enterprises of the region have differences both by the pine stands area and by the annual area of $D$. pini for 
2010-2017 (Tab. 2). Very weak and insignificant correlation $\left(\mathrm{r}=0.36 \pm 0.54 ; \mathrm{t}_{\text {fact. }}=0.67 ; \mathrm{t}_{0.05}=3.18\right)$ was evaluated between the pine stands area and the annual area of $D$. pini foci.

Analysis of the area dynamics of $D$. pini foci in different forest $\&$ hunting enterprises does not allow revealing any regularity (Fig. 2). The difference between $D$. pini foci area dynamics in different FHE was significant $\left(\mathrm{F}_{\text {fact }}=4.32 ; \mathrm{F}_{0.05}=2.64 ; \mathrm{P}=0.006\right)$.

For 2010-2017, there was one maximum of foci area in SE 'Zburyivske FHE' in 2011 with further decrease of foci area to about 3000 hectares, keeping such levels up to 2017. In SE 'Holoprystanske FHE', the maximums of foci area were observed in 2010, 2012 and 2016, with the trend to its increase to almost 5000 hectares in 2017. In SE 'Velykokopanivske FHE', the same trend was revealed with maximums in 2012, 2015 and 2017.

Correlation between annual area of $D$. pini foci in different FHE was weak and insignificant $(\mathrm{r}-0.05-0.66$; $\mathrm{t}_{\text {fact. }}$ 0.12-2.88; $\left.\mathrm{t}_{0.05}=3.18\right)($ Tab. 3).

The explanation of such dynamics of $D$. pini foci area may be found when considering the distribution of infested area by threat level.

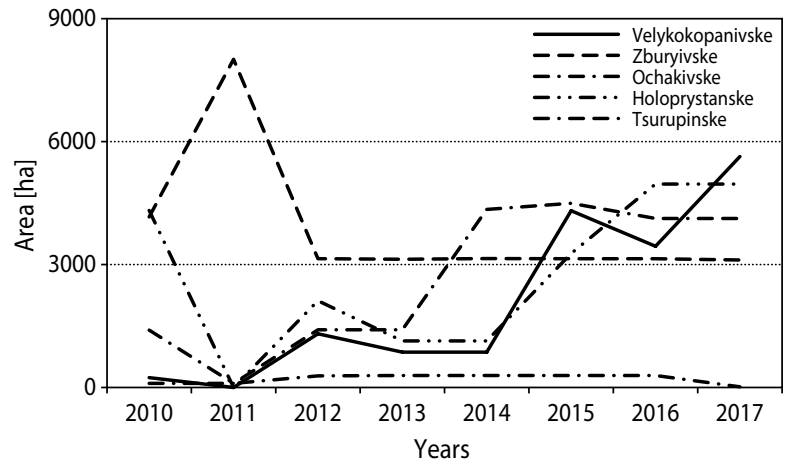

Figure 2. Dynamics of area of Diprion pini foci in different State Forest and Hunting Enterprises of the Low Dnieper region $(2010-2017)\left(\mathrm{F}_{\text {fact }}=4.32 ; \mathrm{F}_{0.05}=2.64 ; \mathrm{P}=0.006\right)$

Analysis of annual foci area of D. pini distribution by the level of stand damage threat (see Tab. 2) shows, that from 59.3 to $79.1 \%$ of this area include the stands with not more than $25 \%$ of foliage damage). It is accepted (Tymchenko et al. 1988) that implementation of pest control measures using insecticides are necessary only if the threat of stand damage exceeds $30 \%$. Since the requirements of statistical reporting to distinguish

Table 2. Severity of Diprion pini outbreaks in the forests of the State Forest and Hunting Enterprises of the Low Dnieper region (2010-2017)

\begin{tabular}{|c|c|c|c|c|c|c|c|c|}
\hline \multirow{4}{*}{$\begin{array}{c}\text { State forest and hunting } \\
\text { enterprises }\end{array}$} & \multirow{4}{*}{$\begin{array}{c}\text { Pine stand } \\
\text { area, } \\
\text { hectares }\end{array}$} & \multicolumn{7}{|c|}{ Foci area, hectares } \\
\hline & & \multirow{3}{*}{$\begin{array}{l}\text { maxi- } \\
\text { mal }\end{array}$} & \multirow{3}{*}{ specific } & \multicolumn{5}{|c|}{ mean annual } \\
\hline & & & & \multirow{2}{*}{ total } & \multicolumn{4}{|c|}{ including with stand damage threat* } \\
\hline & & & & & $\leq 25 \%$ & $26-50 \%$ & $51-75 \%$ & $>75 \%$ \\
\hline 'Velykokopanivske FHE' & $10,262.3$ & 5,636 & 203.0 & 2083.6 & $1539.9 / 74.0$ & $415.6 / 19.9$ & $50.4 / 2.4$ & $77.8 / 3.7$ \\
\hline 'Holoprystanske FHE' & $12,843.8$ & 4,964 & 213.2 & 2738.3 & $1713.8 / 62.6$ & $895.3 / 32.7$ & $110.4 / 4.0$ & $18.9 / 0.7$ \\
\hline 'Zburyivske FHE' & $5,922.3$ & 8,009 & 654.0 & 3873.0 & $2887.4 / 74.6$ & $706.9 / 18.2$ & $236.8 / 6.1$ & $42.0 / 1.1$ \\
\hline 'Tsurupinske FHE' & $12,839.3$ & 4,495 & 195.7 & 2513.0 & 1987.5/79.1 & $439.5 / 17.5$ & $23.8 / 0.9$ & $62.3 / 2.5$ \\
\hline 'Ochakivske FHE' & $3,709.1$ & 1,400 & 100.0 & 370.9 & $219.6 / 59.3$ & $151.1 / 40.7$ & $0.0 / 0.0$ & $0.1 / 0.03$ \\
\hline
\end{tabular}

${ }^{*}$ Denominator is the part of total mean annual foci area, $\%$.

Table 3. Correlation between annual area of $D$. pini foci in different State forests and the hunting enterprises of the Low Dnieper region (2010-2017)*

\begin{tabular}{|l|c|c|c|c|}
\hline \multicolumn{1}{|c|}{ FHE } & Velykokopanivske & Holoprystanske & Zburyivske & Tsurupinske \\
\hline Holoprystanske & $0.69 \pm 0.30(2.31)$ & 1.00 & - & - \\
\hline Zburyivske & $-0.48 \pm 0.36(1.35)$ & $-0.51 \pm 0.35(1.46)$ & 1.00 & - \\
\hline Tsurupinske & $0.76 \pm 0.26(2.88)$ & $0.40 \pm 0.37(1.08)$ & $-0.61 \pm 0.32(1.89)$ & 1.00 \\
\hline Ochakivske & $-0.42 \pm 0.37(1.12)$ & $0.29 \pm 0.39(0.74)$ & $-0.05 \pm 0.41(0.12)$ & $-0.45 \pm 0.36(1.24)$ \\
\hline
\end{tabular}

${ }^{*} \mathrm{r} \pm \mathrm{Sr}$; in brackets $\mathrm{t}_{\text {fact. }} ; \mathrm{t}_{0.05}=3.18$. 
the gradation of such threat ('26-50\%', '51-75\%' and 'over $75 \%$ '), we considered the appropriate distribution of $D$. pini foci area in the pine stands of Low Dnieper region.

As we can see from Table 2, the stands with the threat of $26-50 \%$ damage by D. pini were from $17.5 \%$ from annual foci area in SE 'Tsurupinske FHE' to $40.7 \%$ from the annual foci area in SE 'Ochakivske FHE'. The stands with the threat of $51-75 \%$ damage by this pest were absent in SE 'Ochakivske FHE' and made up $0.9-6.1 \%$ from annual foci area in other forest $\&$ hunting enterprises. The area of stands with the threat of over $75 \%$ damage by $D$. pini was very low -0.1 hectare, or $0.03 \%$ in SE 'Ochakivske FHE' and $0.7-3.7 \%$ from the annual foci area in other FHE (see Tab. 2).

Considering that stand treatments with insecticides including application of biocontrol agents are prescribed only in the case of stand damage threat is not less than $26 \%$, we have calculated the total area of $D$. pini foci with the threat of stand damage over $25 \%$ (that is the sum of areas with a threat of $26-50$, 51-75 and over 75\%), and with the threat of stand damage over $50 \%$ (that is the sum of areas with a threat of 51-75 and over 75\%). Then we sorted the analysed forest enterprises by foci area with stand damage threat over $75 \%$ (Fig. 3 ).

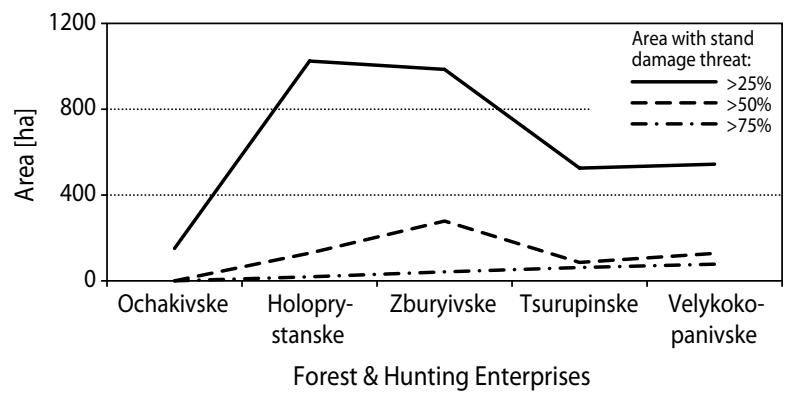

Figure 3. Mean annual foci area of Diprion pini with stand damage threat over 25, 50 and $75 \%$ in the forests of the State Forest and Hunting Enterprises of the Low Dnieper region (2010-2017)

It can be seen that the total area of $D$. pini foci with the threat of stand damage over $25 \%$ was from 151.3 hectares in SE 'Ochakivske FHE' to 985.6 hectares in SE 'Zburyivske FE' and 1024.5 hectares in SE 'Holoprystanske FHE'. Such area must be taken into account during the planning of forest treatment with insecticides.
Representation of dynamics of $D$. pini focal area by individual levels of threat gives the possibility to see the regularities in this process. So, two waves of $D$. pini dynamics with maximums in 2012 and 2015 can be seen for SE 'Velykokopanivske FHE' (Fig. 4) and SE 'Tsurupinske FHE' (Fig. 5) with the highest threat level in 2015 .

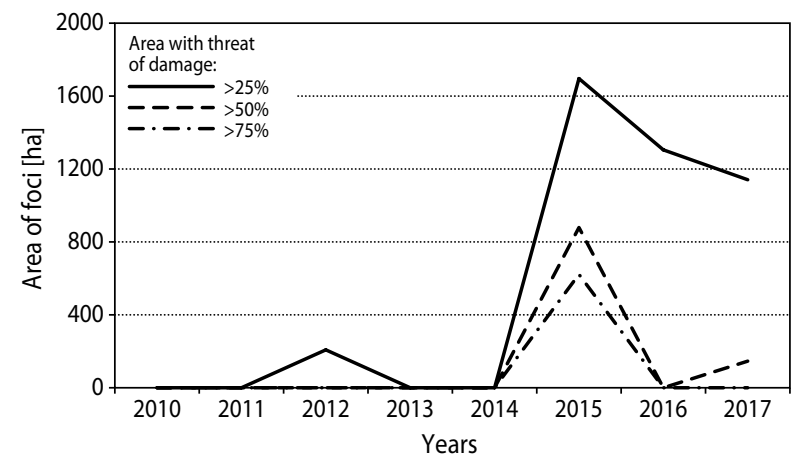

Figure 4. Dynamics of the area of Diprion pini foci with stand damage threat over 25,50 and $75 \%$ in the forests of SE 'Velykokopanivske FHE' (2010-2017)

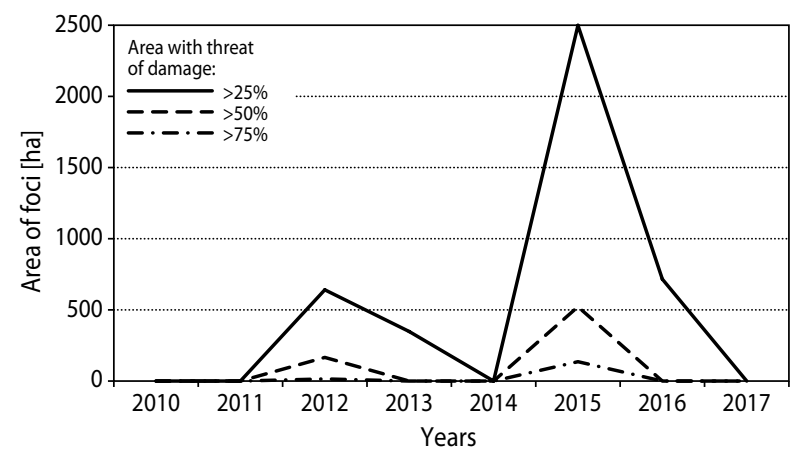

Figure 5. Dynamics of the area of Diprion pini foci with stand damage threat over 25,50 and $75 \%$ in the forests of SE 'Tsurupinske FHE' (2010-2017)

Evaluation of dynamics of stand damage threat in $D$. pini foci, taking into account their distribution by damage threat level and calculation of the mean score of stand damage threat $(\mathrm{T})$ shows that in the most of FHE, there were three outbreak maximums for the analysed years (2010-2017), particularly in 2010 (or 2009?), 2012 and 2015. In SE 'Ochakivske FHE', there was only one maximum in 2010 (or 2009?), and in SE 'Tsurupinske FHE' there were two maximums in 2012 and 2015 (Fig. 6). 


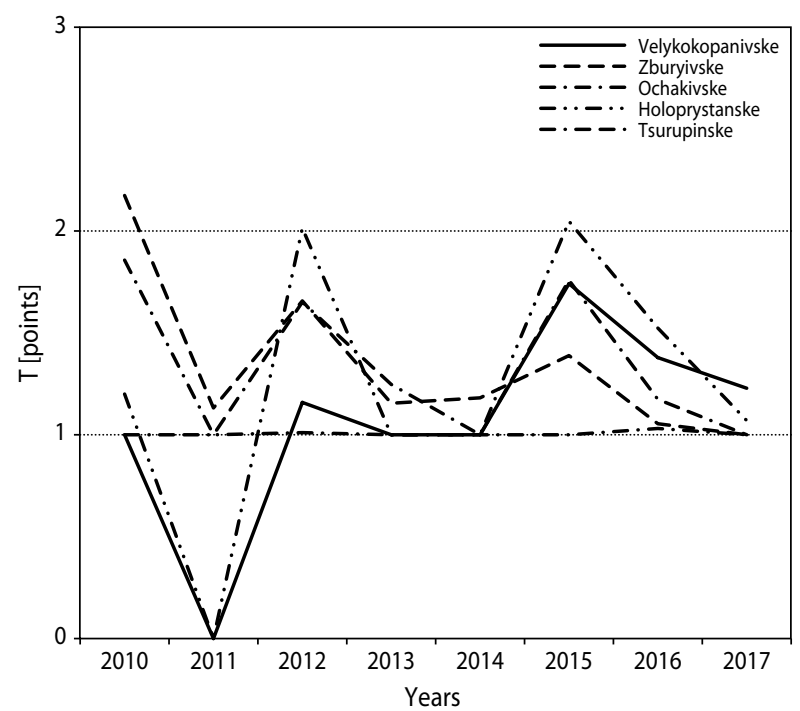

Figure 6. Dynamics of mean score of a forest damage threat (T) in Diprion pini foci in the forest stands of the State Forest and Hunting Enterprises of the Low Dnieper region (2010-2017)

Analysed data show that each outbreak of D. pini in Low Dnieper region lasts no more than three years, and an interval between separate outbreaks makes three or six years. It refers to the publications on outbreak duration for seven generations of the pest (Tymchenko et al. 1988). At the same time, when summarizing data by the whole region, the small oscillations in population dynamics of separate forests are smoothed out (see Fig. 1).

\section{Discussion}

Pine stands were planted on the moving sands of Low Dnieper region, where the forest was absent for hundreds years. Insect pests gradually migrated there from neighbouring trees, shelter belts or with planting material (Nazarenko 2000). Therefore, outbreaks of D. pini in Low Dnieper region were for the first time registered at the end of the seventies of the last century, when pine plantations achieved about 30 years old.

For (1979-2017) five notable maximums of the area of D. pini, foci were registered in 1982, 1993, 2002, 2006 and 2017. An interval between maximums was from 4 to 11 years, in average 9 years. At the same time, only the first outbreak had clear time limits. The outbreaks in nineties lasted about 10 years, because of dif- ferent attractiveness, resistance and tolerance of each forest plot to infestation (Meshkova 2009).

Increase of annual area of $D$. pini foci was 1.5 times for 1979-1998, and for 1999-2017, it was not significant, which can be explained by rather a small sample of years.

The absence of significant correlation between pine stands area and annual area of $D$. pini foci in different forests might be explained by different forest site conditions, age and relative density of stocking in particular stands, which determine the attractiveness of forest plots for this pest (Meshkova 2009; Blomqvist et al. 2016; Kosunen et al. 2017).

The data on $D$. pini foci area in different FHE for 2010-2017 were analysed by the threat of stand damage. Considering only that area having over $25 \%$ threat of stand damage allows determining clear timing of outbreaks and their scale. Such area must be taken into account during the planning of forest treatment with insecticides.

Representation of dynamics of $D$. pini focal area for individual levels of threat gives the possibility to see the regularities in this process, particularly to reveal the mutual years of outbreak of $D$. pini with maximums in 2012 and 2015, three outbreak maximums in three FHE, two outbreaks in one FHE and one outbreak in one FHE and three or six years interval between separate outbreaks.

Analysis of $D$. pini outbreak history in Ukraine shows that the mean interval between outbreaks varies for different foliage browsing insects and regions of Ukraine. For Diprion pini, it is 9 years (8-11 years) (Meshkova and Davydenko 2011).

Comparing the results for $D$. pini with a similar approach to the analysis of $N$. sertifer outbreak history for the same period shows the coinciding maximum of these pest populations in 2012, but more often outbreaks for multivoltinous $D$. pini.

Presented study show that outbreak of $D$. pini in Low Dnieper region repeats every three years. It may be explained by several causes.

Firstly, the recent increase of frequency of outbreaks for this pest may be explained more often by the development of abundant autumn generation due to successful termination of diapause in conditions of climate warming (Heine et al. 2014).

The second case is the consequence of the use of insecticides (including biocontrol agents, e.g., en- 
tomopathogenic viruses) with abrupt decrease of population density and survival of the most resistant and fertile specimens, and rapid population recover (Meshkova 2009).

The third cause of outbreak frequency increase is the diversity of relief and forest site conditions even within one forest stand. Therefore, pest population density increases in different years in different plots, which gives the impression of permanent outbreak in the forest or even in the region (Meshkova et al. 2017).

The fourth cause is connected with the indication in the reports that the whole area is with $D$. pini presence, while the foci are the plots with increased pest population, which can cause stand damage over 30\% (Tymchenko et al. 1988).

There is one more hypothesis that requires verification. It is known (Schwenke 1964; Sharov and Safonkin 1982; Eichhorn 1983) that D. pini can develop only spring generation in one year and only autumn generation in the other years. Sometimes individuals of this tribe cross (particularly in the years with late development of spring generation larvae and their estivation) (Geri 1988), but usually they develop as different populations. So, we can suppose that no repeating of $D$. pini outbreak every three years has been observed but outbreaks of its different populations for every six years.

\section{Conclusions}

In the afforested sands of Low Dnieper region, the first outbreaks of common pine sawfly (Diprion pini) were registered at the end of the seventies of the last century, when the plantations of Pinus sylvestris and Pinus pallasiana achieved about 30 years old.

In the regional scale for 1979-2017, five notable outbreaks of D. pini were registered in 1982, 1993, 2002, 2006 and 2017. An interval between maximums was from 4 to 11 years, in average 9 years. The growth of D. pini foci area in 1979-1998 as compared to 1999-2017, as well as correlation between pine stands area and annual area of $D$. pini foci in different forest $\&$ hunting enterprises (FHE) was not statistically significant.

Graphical analysis of dynamics of $D$. pini focal area for 2010-2017, considering the individual threat levels, confirms the fact of three outbreaks for this period in the three FHE, two outbreaks in one FHE and one outbreak in one FHE. An interval between separate outbreaks makes three or six years.

\section{References}

Barre, F. at al. 2002. Preference and performance of the sawfly Diprion pini on host and non-host plants of the genus Pinus. Entomologia Experimentalis et Applicata, 102, 229-237. https://doi.org/10.1046/ j.1570-7458.2002.00944.x

Blomqvist, M. at al. 2016. Impacts of natural enemies and stand characteristics on cocoon mortality of the pine sawfly Diprion pini in a Fennoscandian boreal forest. Silva Fennica, 50 (5), article id 1615. http:// dx.doi.org/10.14214/sf.1615

Eichhorn, O. 1983. Diapause development of the common pine sawfly (Diprion pini L.) (Hym., Diprionidae) and their parasites (in German). Zeitschrift für Angewandte Entomologie, 95, 482-498.

Geri, C. 1988. The pine sawfly in central France. In: Dynamics of forest insect populations: patterns, causes and implications (ed.: A. Berryman). Plenum Press, New York, 377-405.

Haynes, K.J., Tardif, J.C., Parry, D. 2018. Drought and surface-level solar radiation predict the severity of outbreaks of a widespread defoliating insect. Ecosphere, 9 (8). https://doi.org/10.1002/ecs2.2387

Haynes, K., Allstadt, A., Klimetzek, D. 2014. Forest defoliator outbreaks under climate change: effects on the frequency and severity of outbreaks of five pine insect pests. Global Change Biology, 20 (6), 2004-2018. http://doi.org/10.1111/gcb.12506

Kosunen, M. et al. 2017. Influence of soil and topography on defoliation intensity during an extended outbreak of the common pine sawfly (Diprion pini L.). IForest, 10, 164-171. doi: 10.3832/ifor2069-009 [online 2016-11-19].

Meshkova, V.L. 2009. Seasonal development of the foliage browsing insects (in Russian). Novoe slovo, Kharkov.

Meshkova, V.L., Kolienkina, M.S. 2016. Outbreaks of pine sawflies in the forest stands of Luhansk region (in Ukrainian). Planeta-Print, Kharkiv.

Meshkova, V.L., Nazarenko, S.V., Kasych, T.G. 2017. Dynamics of European pine sawfly foci area in the 
stands of Low Dnieper region in 2010-2017. Forestry and Forest Melioration, 130, 215-222.

Meshkova, V., Davydenko, K. 2011. Foliage browsing insects outbreaks in Ukraine before and after global warming. In: Biotic risks and climate change in forests (eds.: H. Delb, S. Pontuali). Proceedings of the Working Party 7.03.10 Methodology of Forest Insect and Disease Survey in Central Europe, 10th Workshop September 20th-23rd, 2010, Freiburg, Germany. Berichte Freiburger Forstliche Forschung, 89, 18-25.

Nazarenko, S.V. 2000. Insect pests of pine stands of the Low Dnieper sands. The Kharkov Entomological Society Gazette, 8 (2), 117-121.

Möller, K., Hentschel, R., Wenning, A., Schröder, J. 2017. Improved outbreak prediction for common pine sawfly (Diprion pini L.) by analyzing floating 'Climatic Windows' as keys for changes in voltinism. Forests, 8 (9), 319. DOI:10.3390 / f8090319

Nazarenko, S.V. 2000. Insect pests of pine stands of the Low Dnieper sands. The Kharkov Entomological Society Gazette, 8 (2), 117-121.

Neuvonen, S., Viiri, H. 2017. Changing climate and outbreaks of forest pest insects in a cold northern country, Finland. In: The Interconnected ArcticUArctic Congress 2016, 49-59. Springer, Cham.
Nevalainen, S., Sirkiä, S., Peltoniemi, M., Neuvonen, S. 2015. Vulnerability to pine sawfly damage decreases with site fertility but the opposite is true with Scleroderris canker damage; results from Finnish ICP Forests and NFI data. Annals of Forest Science, 72 (7), 909-917. DOI 10.1007/s13595014-0435-8

Schwenke, W. 1964. Grundzüge der Populationsdynamik und Bekämpfung der Gemeinen Kiefernbuschhorn-Blattwespe. Diprion pini L. Zeitschrift für Angewandte Entomologie, 54, 101-107.

Sharov, A.A., Safonkin, A.F. 1982. Spontaneous and inductive processes in the mechanism of reactivation of common pine sawfly Diprion pini (Hymenoptera, Diprionidae) (in Russian). Zoological Journal, 61 (8), 1171-1179.

Tymchenko, H.A. et al. 1988. Reference book on forest protection from pests and diseases (in Russian). Urozhay, Kyiv.

Vinogradov, V.N. 1964. Complex development of the Low Dnieper sands (in Russian). Mayak, Odessa.

Ziesche, T.M. 2017. Tree growth indicates resource quality for foliage-feeding insects: Pattern and structure of herbivore diversity in response to productivity. Ecological Indicators, 83, 249-259. https://doi.org/10.1016/j.ecolind.2017.07.053 